\title{
Educational Possibilities in Contemporary Schools
}

This article aims to show how a school's educational potential has an effect on the formation of students who will be able to function well in the different areas of a knowledge-based society and maintain good relationships with other people. To this end, this article demonstrates how a school that uses its human and organizational capital should provide students with educational experiences that will prepare them for the most urgent challenges of adult life in a knowledge-based society. This article concludes by showing how teaching religion can benefit education and discussing how schools can utilize their spiritual potential.

Key words: education, upbringing, school, religious education.

A post-industrial society based on knowledge is predicted to be the next stage of social development in the new social order and vision of the future. After the long phase of industrial and post-industrial society has passed, the process of forming a knowledge-based civil society will occur. ${ }^{1}$ Currently, one can observe that rapid changes and transformations are taking place in this area. ${ }^{2}$ The question arises, therefore, whether this process will be spontaneous, or whether it will necessitate the creation of an educational strategy that will be able to

\footnotetext{
$1 \quad$ M. Nowak, Czy szkota ma przekazywać wiedzę, czy też wychowywać? "Paedagogia Christiana" 29(2012), no 1, pg. 105. woju, Cracow 2012 pg. 44.
} 
address the need to educate people to live in the digital age. ${ }^{3}$ In this context, the role of education in a situation where discontinuities in social life are increasing and where the future of individuals or groups is uncertain is called into question. ${ }^{4}$ As the world strives to create Catechetics knowledge-based societies, no one questions the educational role of schools. At the same time, however, very few people are satisfied with the way that contemporary schools currently fulfill their roles in the current social situation. This is due to the fact that there are no easy solutions to the problem that are occurring in this area right now. This does not exempt schools, however, from their obligation to search for solutions to these problems. ${ }^{5}$

\section{The Aims of Education and Upbringing}

Upbringing and education within the school system should meet the requirements of modernity. ${ }^{6}$ The fundamental constitutional principles of the state determine the most important features of education. The current political system in Poland is a pluralistic democracy, and the economic system is a free market wherein people are free to choose their own professional and ideological priorities. ${ }^{7}$ New legal regulations require that Polish schools provide students with the circumstances necessary for their development, and prepare students to fulfill their family and civic duties based on the principles of solidarity, democracy, justice, and freedom. ${ }^{8}$ As for the goals of education, it is clear that it is necessary to teach students the importance of: proactivity, being prosocial, social cooperation, tolerance, integrity,

3 See L. Bakiera, B. Harwas-Napierała, Wzory osobowe w rozwoju człowieka, Poznan 2017, pg. 9.

A. Koźmiński, Zarządzanie w warunkach niepewności. Podręcznik dla zaawansowanych, Warsaw 2004, pg. 7.

See J. Biernat, Wymogi globalizacji - społeczeństwo wiedzy, in Regionalizacja i globalizacja w gospodarce światowej, ed. J. Rymarczyk, vol. 1, Wroclaw 2003, pg. 78.

$6 \quad$ W. Bokajło, Edukacja w Polsce wobec wyzwań konkurencyjności Unii Europejskiej - kilka uwag wprowadzajacych, in Edukacja w Polsce wobec wyzwań konkurencyjności Unii Europejskiej, ed. W. Bokajło, A. Wiktorska-Święcicka, Wroclaw 2008, pg. 7n.

7 See B. Milerski, Odnowienie umystu, czyli o refleksyjnym charakterze ksztatcenia religijnego, in Świat idei edukacyjnych, ed. W. Szulakiewicz, Torun 2008, pg. 179. 
responsibility, proper relationships with others, and forming one's own religious worldview. ${ }^{9}$

Contemporary schools are obliged to develop educational programs that respond to the needs of the environment in which these programs are implemented. In practice, this means that many programs can exist. However, since no one has yet to find a resolution to the problem of education, one must assume that the only way to deal with this issue is to allow for diversity and to seek out solutions to particular problems as they arise in specific communities.

Existing educational systems propose either strategies to achieve certain goals and values, or they uphold certain personal examples for students to follow. Both approaches have their proponents and opponents. ${ }^{10}$ Since the individual who makes rational and independent decisions is the object of education, schools as educational institutions must create the conditions necessary for individuals to develop, form a worldview, and learn a system of values. In addition, schools must teach students that being independent means being responsibile for one's decisions. ${ }^{11}$ In order to make this possible, however, it is necessary for schools to create the appropriate educational system that will implement this assumption. It is impossible to separate upbringing from education, which is effective only when the schools foster an educational environment that is pro-development. In order for this to happen, it is necessary to: formulate the aim of education and upbringing, define the methods for achieving these aims, establish adequate institutions within schools that can implement these methods, and involve all members of the school community in the implementation process. True educational work requires the help, support, and involvement of many entities. ${ }^{12}$ Procedures that must be applied within the realm of a school are described below.

\section{Methods for Schools to Realize Their Educational Aims}

In realizing its ambitious educational aims, a school must become a place where independent entities are constantly involved in

$9 \quad$ Ibid., Article 1, point 1.

10 See E. Fromm, Escape from Freedom, Holt Publisher, 1969.

11 M.Nowak, Wspótczesna koncepcja wychowania w szkole, in Wychowanie w szkole od bezradności ku możliwościom, eds. R. Chałupniak, T. Michalewski, E. Smak, Opole 2014, pg. 58.

12 J. Ratzinger, God and the World, trans. Henry Taylor, Ignatius Press, 2013. 
education and where each person has clear rights and duties. ${ }^{13}$ Those who participate in the educational process at school must fulfill two conditions: 1) they must have mutual respect for the autonomy of others, and 2) awareness of the purpose and aims of their collaboration.

Catechetics The collective group cannot dominate the individual because then it will be impossible to carry out a particular activity. ${ }^{14}$

The students, teachers, management, and parents are the ones who actively create a school's educational environment. In some school arrangements, school staff (who are not teachers) also help create the school's educational environment on a daily basis. ${ }^{15}$ Among those involved, three kinds of relationships exist among students and teachers: an authoritarian relationship, a partnership, and an intermediary relationship. ${ }^{16}$

An authoritarian relationship between teachers and students exists in so-called traditional school structures. In such a relationship, the student is subordinate to the teacher. ${ }^{17}$ According to this model, students and teachers have different rights. The teacher knows what is good for the student because the system makes the teacher an authority to whom the student should be completely submissive. ${ }^{18}$ When a conflict arises, the teacher defers to his own point of view, ${ }^{19}$ and the student must be obedient to the teacher, follow instructions, and refrain from showing any emotions. As an immature individual, the student's only right is to learn. Experience demonstrates that the authoritarian relationship creates a rift between teachers and students. Rather than instilling respect in students, it breeds disrespect and the

13 See M.Szymański.Socjologia edukacji. Zarys problematyki, Cracow 2013 pg. 65. K. Konarzewski, O wychowaniu w szkole, in Sztuka nauczania. Czynności nauczyciela, ed. K. Kruszewski, Warsaw 207, pg. 284n.

Por. G. Mazurkiewicz, Edukacja i przywództwo. Modele mentalne jako bariery rozwoju, Cracow 2012 pg. 44.

16 Por. H. Kopiec, Szkoła wobec zagrożenia załamania się ładu moralnego, in Edukacja w procesie przemian cywilizacyjnych i kulturowych. Part 3, eds. E. Holona, E. Nycz, Opole 1995, pgs. 35-45.

17 A. Sobala-Zbroszczyk, Szkoła jako środowisko wychowawcze, "Nowa szkoła" 5(1999), pg. 5n.

18 B.Śliwerski, Wychowanie.Pojęcie-znaczenia-dylematy,in Wychowanie.Pojęcia - procesy - konteksty. Interdyscyplinarne ujęcie, vol. 1, eds. M. Dudzikowa, M. Czerepaniak-Walczak, Gdansk 2007, pg. 38.

19 See Z. Struzik, Program wychowawczy oparty na wartościach, Warsaw 2007, pg. 9 . 
façade of obedience..$^{20}$ In such an environment, the school becomes a place of struggle, where two separate worlds function side-by-side. This makes both education and upbringing a farce. ${ }^{21}$

In partnership, students and teachers work together. As different entities, they have heterogeneous duties and a different scope of responsibility. ${ }^{22}$ Nevertheless, both students and teachers are entitled to equal rights, which allows them to communicate with each other in a transparent manner by clearly articulating their opinions, needs, and expectations. In this environment, teachers and students do not seek to gain an advantage over each other; instead, they complement each other. The teacher interacts with the students in a friendly way and, rather than trying to impose anything on them, seeks instead to persuade them..$^{23}$ In this relationship, the students are aware of their influence on what their education will look like, and this is why they communicate their needs and listen to others easily.

While it might seem that the partnership model meets current demands, it does entail certain dangers when it is implemented in the school setting. In this relationship, the teachers' role is to educate and form students, and the teachers' credentials and competence justify the their dominant role in the classroom..$^{24}$ In turn, it is the students' role to develop, shape their worldview, and acquire the knowledge and skills necessary to live as adults. ${ }^{25}$ Therefore, according to this model, students and teachers cannot be equal partners in the full sense of the word. When implemented in a realistic school setting, however, the beautiful, idealistic, and utopian concept of partnership turns against those who support it because teachers encounter difficulties if fulfilling their own obligations, and the students do not work toward obtaining the knowledge and skills that they need because they do

$20 \quad$ Por. A. Krajewska, Kryzys autorytetów w wychowaniu, in Autorytet w wychowaniu i edukacji, ed. D. Łażewska, Józefów 2013 pg. 112n (112-124).

E. Lemańska-Lewandowska, Nauczyciele a dyscyplina w klasie szkolnej, Bydgoszcz 2013, pg. 22.

R. MacKenzie, Kiedy pozwolić? Kiedy zabronić?, trans. O. Waśkiewicz, Gdansk 2003, pgs. 147-155.

Por.A.B.Kwiatkowski, Wzorceosobowe działaczy społeczno-politycznych, Pultusk 2013, pg. 56.

Por. L. Bakiera, B. Harwas-Napierała, Wzory osobowe w rozwoju człowieka, pg. 91. 
not feel compelled to do so. In this way, development becomes an educational fiction. ${ }^{26}$

The only way out of this impasse is to create a relationship model that is advantageous to both teachers and students, but also avoids

Catechetics the disadvantages of the models mentioned above. The transitional relationship model achieves both. According to this model, teachers clearly set the limits of the behavior that they will tolerate; they always try to present their point of view in a rational manner; and they justify the boundaries that they have set. Such teachers are consistent, they react decisively in situations where students cross the boundaries, and they do not hide their emotions. ${ }^{27}$ In this model, students know the aims and values that the established rules are created to achieve. Students are aware that, by breaking or rejecting these rules, they can no longer be members of the school community. ${ }^{28}$

The relationships mentioned above are insufficient to enable effective education. Rather, an entire pedagogical team made up of individuals who work together is necessary to create and maintain a flexible system to meet the demands of today. Therefore, it is necessary to establish in schools educational institutions that help implement the intermediary model described above. ${ }^{29}$

\section{School Educational Institutions}

Organizational groups on school campuses are very important to maintain the stability of an educational system. Educational institutions should help mediate how people react in difficult situations. They should also serve as a resource to which every member of the school community who finds himself in crisis can appeal. ${ }^{30}$ Such a body is necessary because the effectiveness of a school's educational system is determined by the way in which conflicts that arise on campus are resolved.

The most important institution in an educational system should be a social contract into which the teachers and students enter. This contract does not pertain to the teacher's essential work. This social contract should enable both parties to know how to formulate their

Por. A. Sobala-Zbroszczyk, Szkoła jako środowisko wychowawcze, pg. 9.

T. Szkudlarek, Pedagogika krytyczna, in Pedagogika. Podręcznik akademicki, Vol. 1, eds. Z. Kwieciński, B. Śliwerski, Warsaw 2004, pg. 367

SeeA.B. Kwiatkowski, Wzorce osobowe działaczy społeczno-politycznych,pg. 15.

Z. Struzik, Program wychowawczy oparty na wartościach, Warsaw 2007, pg. 10.

Act of December 14, 2016. Educational Law (Dz. U. z 2017 r. poz. 59, 949 i 2203). 
needs and express the real intentions behind their needs..$^{31}$ In an educational system, contracts demonstrate the most effective yet simplest ways to resolve conflicts. ${ }^{32}$ The purpose of contracts is that they make it possible for individuals to come to a rational compromise that will satisfy both parties and strengthen their subjectivity. In an educational sense, a contract serves to make both parties aware of their rights and responsibilities. ${ }^{33}$ At the beginning of each academic year, every teacher should create an agreement with the class that defines the rules of working together in a community. ${ }^{34}$ In this way, there is something to appeal to in case a conflict occurs.

Social agreements are real and effective educational tools. Because of these agreements, students learn responsibility and respect for others as well as good problem-solving methods. By implementing social agreements, schools show their students that they must abide by certain social rules. Contracts also specify the boundaries and the consequences that result when these boundaries are crossed..$^{35} \mathrm{How}$ ever, even when an agreement has been established, it cannot foresee or anticipate every situation. For example, there are situations wherein one party wants to achieve its goal but, in order to do so, it is necessary to obtain the consent of the other party, which does not wish to give its consent. In this situation, it is impossible to enter into an agreement because a contract is supposed to ensure that both parties benefit. In addition, another situation can occur in which one party has legitimate concerns that its interests are not being sufficiently met. Hence the existence of an educational institution that is oriented toward working in a sustainable manner, meaning via a contract.

A contract is an agreement that is proposed by one party, most often in a situation where there is a conflict of interest, and formulated to define mutual obligations and ensure both parties with a sense of security. A contract is also a one-sided agreement to which another party must give its consent if it wishes to resolve a current problem. To this end, a contract should be written or typed and signed by both parties.

$31 \quad$ A Olczak, Umowa społeczna z dzieckiem jako strategia pracy otwierajacej na społeczeństwo, http://www.ipp.uz.zgora.pl/ aolczak/teksty/21.pdf (01.22.2018).

Por. A. Sobala-Zbroszczyk, Szkoła jako środowisko wychowawcze, pg. 11.

M. Łuszczyńska, Umowa społeczna jako fundament życia zbiorowego, "Studia Iuridica Lublinensia" 12(2014), pg. 43 (43-54).

For more on this topic, please see: E. Góralczyk, Umowa z klasa, Warsaw 2009.

Por. L. Dziewięcka-Bokun, Polska szkoła wyższa wobec szans i wyzwań europejskiej przestrzeni edukacyjnej, in Edukacja w Polsce wobec wyzwań konkurencyjności Unii Europejskiej, pg. 57 (51-62). 
It is should also state what the consequences are when the contract is broken. It is possible to enter into a contract with a single student, a group, or an entire class. ${ }^{36}$ The educational aim of this institution is to show individuals who engage in social life that they have their rights Catechetics and can defend them. The refusal to follow a particular law always entails certain consequences that an individual must suffer in order to maintain the possibility of further cooperation.

In schools, conflicts that the parties are unable to resolve can occur. In this case, it is necessary to seek resolution through the help of someone else, such as a negotiator or mediator. This individual should be a member of the school community and, therefore, familiar with the school's rules; able to remain impartial; and considered an authority by both parties involved in the conflict. ${ }^{37}$ Most often, only the school principal can fulfill this role.

Within a school environment, there are hundreds of other minor and troublesome conflicts that need to be resolved. Therefore, so-called "quick response" educational institutions are necessary to enable all teachers to follow a consistent educational policy on a daily basis. ${ }^{38}$ Restrictions also have their place in the educational system, but they should be used only as a last resort. Only multiple and diverse educational tools make it possible for educators to teach responsibility and effectively solve school conflicts.

\section{Subjects of the Educational Process}

The roles of individual entities are apparent in the activities of the educational institutions described above. A school is dynamic environment that includes everyone who participates in it. For this reason, all of the entities that operate within a school influence the educational process. ${ }^{39}$ So, what role do other entities play in the educational process in order to ensure that education is consistent and achieves the desired end(s)?

Teachers have the most contact with students, so their role in education is the most important. ${ }^{40}$ For this reason, teachers must be

B. Brzozowska, Zawieranie kontraktów z uczniami, http://edurada.pl/artykuly/ zawieranie-kontraktow-z-uczniami/ (01.15.2018).

Por. E. Rutkowska, Mediacje $i$ inne sposoby rozwiazywania konfliktów w gimnazjum, Warsaw 2015, pg. 9.

M. S. Szymański, O metodzie projektów, Warsaw 2000, pgs. 7-8.

Por. T. Gordon, Wychowanie bez porażek, Warsaw 1998, pg. 19.

E. Kobyłecka, Nauczyciel wobec wspótczesnych zadan edukacyjnych, Cracow 2005, pg. 12. 
consistent in applying the rules of cooperation in the classroom. Failure to do so destroys any sense of collaboration. It is equally important for teachers to foster good relationships between students and establish and maintain mutual respect and trust. This can be achieved only when teachers abandon the façade of schoolmasters, which gives them a false sense of security; demonstrate to the students that they have their own strengths and weaknesses; and show they are ready to collaborate and be in authentic contact. ${ }^{41}$ The teacher who is also an educator plays a special role here. ${ }^{42}$

Students are indispensible in the education process, and their influence on each other is decisive because they will one day grow up and interact in society. Students are particularly influential when they consciously take advantage of their rights and express their willingness to take responsibility for specific school activities. Student Council is a good way to help students learn to be proactive. ${ }^{43}$

Parent cooperation in difficult situations (i.e. conflicts) is also very important, and such cooperation should take place in the everyday life of the school. ${ }^{44}$ From current practice, it is obvious that "an educator who does not cooperate with parents will have no impact on the student's personality and psychological development. Their cooperative role should be one of teacher-functionaries." 45 It does not have to be standard practice for parents to be present on a school campus. Rather, teachers should invite parents to the school or classroom for designated meetings and regular conversations that do not necessarily have anything to do with difficult situations pertaining to their child. In this way, parents are welcome to the school environment for reasons other than resolving problems related to their children. ${ }^{46}$

The school principal should serve as a negotiator or mediator when resolving particularly difficult conflicts at school. Because of the principal's role, he or she is also someone to whom others can appeal; who can assess the activity of other educational institutions at the school;

${ }_{41} \quad$ Por. A. Aleksander, Drogi i bezdroża, czyli stów kilka o autorytecie nauczyciela w okresie przemian, "Edukacja Dorosłych" 1(1999), pgs. 56-86.

Por. A. Konopnicki, Rola pedagoga szkolnego w rzeczywistości edukacyjnej, in Wychowanie w szkole od bezradności ku możliwościom, pg. 218n.

Por.P.Ziółkowski.Samorząduczniowski:idee, uwarunkowaniai doświadczenia, Bydgoszcz 2014, pg. 9.

$44 \quad$ Educational System Act, September 7, 1991 (Dz.U. 1991 nr 95, poz. 425).

45 E. Kosińska, Rodzice a szkoła, Cracow 1999, pg. 47.

46 Por. K. Hernik, K. Malinowska, Jak skutecznie wspótpracować $i$ komunikować się z rodzicami i społecznościa lokalna, Warsaw 2015, pg. 9. 
and who can make independent decisions in contentious matters. ${ }^{47}$ In the educational process, the principal is only one of many participants. Therefore, the principal should not act as a judge because his or her autonomy could be taken away by other entities in the educaCatechetics tional environment. ${ }^{48}$ The team of educators should meet regularly in order to talk about current problems and share their experiences so that they can learn from each other.

\section{Working Towards Teaching and Educational Schools}

With regard to the turbulent development of civilization that will occur in the next decade, many new phenomena have appeared that dynamically affect contemporary students. ${ }^{49}$ The lives of young people have become saturated with unprecedented technological and scientific progress as well as cultural changes. ${ }^{50}$ The significant number and quality of these changes have had a particular influence on how students function in the contemporary world in the area of norms and values. ${ }^{51}$ Despite schools' educational entities' efforts to achieve the highest pedagogical mastery, radical changes have not taken place in the lives of particular pupils. It is for this reason that Pope Francis wrote the following in his Apostolic Letter Misericordia et Misera:

In a culture often dominated by technology, sadness and loneliness appear to be on the rise, not least among young people. The future seems prey to an uncertainty that does not make for stability. This often gives rise to depression, sadness and boredom, which can gradually lead to despair. We need witnesses to hope and true joy if we are to dispel the illusions that promise quick and easy happiness through artificial paradises..$^{52}$

Por.B. Tołwińska, Kierowanie szkoła: rola dyrektora-partycypacja nauczycieli, in Przywództwo edukacyjne w szkole i jej otoczeniu, eds. S.M. Kwiatkowski, J.M. Michalak, I. Nowosad, Warsaw 2011, pg. 105.

A. Iszczuk, Dyrektor szkoty - pierwszy odpowiedzialny za wychowanie w szkole, in Wychowanie w szkole od bezradności ku możliwościom, pg. 171 (171-176).

Por. A. Kielian, Wychowanie w szkole w dokumentach Unii Europejskiej, in Wychowanie w szkole od bezradności ku możliwościom, pg. 15-16 (11-22).

A. Potocki, Wychowanie religijne w polskich przemianach, Warsaw 2017, pg. 199.

Por. M. Szymański. Socjologia edukacji. Zarys problematyki. Cracow 2013, pg. 65.

$52 \quad$ Francis. Apostolic Letter: Misericordia et Miseria, Vatican City, 2016, 3, https:// w2.vatican.va/content/francesco/en/apost_letters/documents/papa-francescolettera-ap_20161120_misericordia-et-misera.html (05.04.2018). 
Values-based educational programs must fulfill this mission in contemporary schools. ${ }^{53}$ In other words, schools must form their students to follow the natural principle to do what is good for religious motives. ${ }^{54}$

Contemporary Polish curriculum also includes religion. A correct understanding of this issue should resolve the difficult choice that the Catholic Church must make when it proposes educational strategies to modern schools. ${ }^{55}$ Among its priorities, the Catholic Church wants to be educationally relevant and useful; this is why the Church wishes to illuminate educational dilemmas with the light of the evangelical truth. The Church achieves this by demonstrating that, even if the contemporary world's educational ideas distance themselves from God and religion, religion does not distance itself from the world, which it authentically desires to serve. ${ }^{56}$

The General Directory for Catechesis states that "The relationship between religious instruction in schools and catechesis is one of distinction and complementarity: 'there is an absolute necessity to distinguish clearly between religious instruction and catechesis"” (73). When analyzing the educational guidelines for all school subjects through which the school wishes to educate new citizens, it is evident that teaching religion involves a similar realm of activity. ${ }^{57}$ Students are encouraged to be responsible for their own choices, especially those that concern other people. ${ }^{58}$ In this context, the correlative possibilities are almost limitless and should focus on a range of key skills that will be useful to the students during their adult lives.

53 Z. Struzik, Program wychowawczy oparty na wartościach, pg. 9.

54 Por. A. Dulles, The Splendor of Faith: The Theological Vision of Pope John Paul II, The Crossroad Publishing Company, 2003.

55 "If we do not answer simple questions about God, the Commandments, Gospel teaching, the Teaching Office of the Church, the limits of freedom, the way to human emancipation, the right of some to tell others what is important, then we will never really reach education." A. Nalaskowski, Szkoła jako dobro kultury wobec mechanizmów edukacji, "Paedagogia Christiana" 1(1997), pg. 62.

56 Por. M.Zając, Idea Królestwa Bożego w nauczaniu katechetycznym, in Scripturae Lumen. Ewangelia o Królestwie, ed. A. Paciorek, Lublin 2009, pg. 435.

57 S.Ruciński, Wychowaniejako wprowadzenie wżycie wartościowe, Warsaw 1988, pg. 14.

58 Por. Rozporzadzenie Ministra Edukacji Narodowej z dnia 23 grudnia 2008 r. w sprawie podstawy programowej wychowania przedszkolnego oraz ksztatcenia ogólnego w poszczególnych typach szkół (Dz. U. z January 15, 2009, no 4, poz. 17. 
In light of the above, religious education proposes two possible ways to consider the issues that are important to schools. ${ }^{59}$ First, all interactions that occur on a school's campus involve elements that are considered to be morally negative (e.g. competition, eliminating one's opponents, aggression, the desire to win at all cost). Because of this, teaching religion in schools can potentially minimize morally negative values that can manifest in student activities. Second, all school activities involve elements that are morally positive (i.e., cooperation, unity in a group, the principle of "fair play," forgiveness, the ability to apologize and reconcile). Therefore, forming new citizens in a digital age through religious education can strengthen their positive moral values by providing them with supernatural motivation. ${ }^{60}$ Despite the best intentions and efforts of people involved in the educational and formation process, it is not possible to avoid all educational difficulties and crises. Sometimes it is necessary to refer to a religious motivation such as "life has deeper meaning" ${ }^{61}$ when resolving a very difficult problem.

The educational means used until now by so-called "traditional schools" are losing their splendor and spiritual authority. In school, just like in life, individuals have become increasingly more bereft of moral principles and ruthless in the last two decades. Students' criminal behavior toward their peers as well as scandals involving violence have shown the hegemony that dominates noble competition. ${ }^{62}$ From an ethical point of view, the problem is much more complicated. Most likely, there is no middleman who can help heal this situation. Therefore, Christian education-or moral education that is inspired by evangelical principles-should be included among every teacher, trainer, tutor, and educator's duties. ${ }^{63}$ This education should begin early in order to instill in children and youth a stable code of moral values before they develop their own work and professional interests as adults. ${ }^{64}$

$59 \quad$ P. Mąkosa, Szkolna lekcja religii istotnym elementem wychowania $w$ szkole, in Wychowanie w szkole od bezradności ku możliwościom, pg. 353.

See B. Śliwerski, Program wychowawcy szkoły, Warsaw 2001, pg. 28.

P. Mąkosa, Największajest miłość. Ewangelizacyjnykatechizm młodych, Tarnow 2015, pg. 7.

See M. Zając, Agresja wśród młodzieżyjako problem katechetyczny, in Katecheza młodzieży, ed. S. Kulpaczyński, Lublin 2003, pg. 335.

Z. Struzik, Program wychowawczy oparty na wartościach, pg. 10.

Por. S. Dziekoński, Korelacja wychowania w rodzinie, parafii i szkole. Potrzeba i możliwości, in Rodzina - Szkoła - Kościót, Warsaw 2003, pgs. 30-31. 


\section{Conclusion}

When creating an educational system in schools, it necessary to define the aims of education, the methods used to achieve these aims, as well as the role of particular subjects in the educational process. The solutions proposed here illustrate precisely this kind of coherent and consistent system, which seeks to meet the challenges of modern times and create the necessary conditions for students to develop and learn how to live well in a society founded on liberalism and democracy, meaning a knowledge-based society. This educational system should also be based on religious principles.

\section{MOŻLIWOŚCI WYCHOWAWCZE WSPÓŁCZESNEJ SZKOŁY}

Podstawowym celem artykułu jest ukazanie, w jaki sposób potencjał wychowawczy szkoły może wpłynąć na ukształtowanie ucznia, który będzie się sprawnie poruszał w przestrzeniach społeczeństwa opartego na wiedzy, zachowując poprawne relacje z innymi ludźmi. Podjęta będzie próba wskazania, jak szkoła wykorzystując swój kapitał ludzki oraz organizacyjny powinna uczynić edukacyjne doświadczenia uczniów koherentnymi z najpilniejszymi wyzwaniami dorosłego życia w społeczeństwie opartym na wiedzy. Artykuł zakończą wskazania, jak dziełu wychowania może przysłużyć się nauczanie religii. Postulaty końcowe będą dotyczyć wykorzystania potencjału duchowego w edukacji szkolnej.

Słowa kluczowe: edukacja, wychowanie, szkoła, nauczanie religii.

\section{Bibliography:}

1. Bakiera L., Harwas-Napierała B., Wzory osobowe w rozwoju człowieka, Poznan 2017.

2. Bokajło W., Wiktorska-Święcicka A., Edukacja w Polsce wobec wyzwań konkurencyjności Unii Europejskiej, Wroclaw 2008.

3. Brzozowska B., Zawieranie kontraktów z uczniami, http://edurada.pl/ artykuly/zawieranie-kontraktow-z-uczniami/ (Accessed 01.15.2018).

4. Chałupniak R., Michalewski T., Smak E., (eds.), Wychowanie w szkole od bezradności ku możliwościom, Opole 2014.

5. Dudzikowa M., Czerepaniak-Walczak M., (eds.), Wychowanie. Pojęcia procesy - konteksty. Interdyscyplinarne ujęcie, Vol. 1, Gdansk 2007.

6. Dulles A., The Splendor of Faith: The Theological Vision of Pope John Paul II, The Crossroad Publishing Company, 2003. 
7. Francis. Apostolic Letter: Misericordia et Miseria, Vatican City, 2016. https:/w2.vatican.va/content/francesco/en/apost_letters/documents/papafrancesco-lettera-ap_20161120_misericordia-et-misera.html (Accessed: 05.04.2018).

8. Hernik K., Malinowska K., Jak skutecznie wspótpracować $i$ komunikować się z rodzicami i społecznościa lokalna, Warsaw 2015.

9. Holona E., Nycz E., (eds.), Edukacja w procesie przemian cywilizacyjnych $i$ kulturowych. Part 3, Opole 1995.

10. Kobyłecka E., Nauczyciel wobec współczesnych zadań edukacyjnych, Cracow 2005.

11. Kwiatkowski S.M., Michalak J.M., Nowosad J., (eds.), Przywództwo edukacyjne w szkole i jej otoczeniu, Warsaw 2011.

12. Lemańska-Lewandowska E., Nauczyciele a dyscyplina w klasie szkolnej, Bydgoszcz 2013.

13. Łażewska D., (ed.), Autorytet w wychowaniu i edukacji, Jozefow 2013.

14. Łuszczyńska M., Umowa społeczna jako fundament $\dot{z} y c i a$ zbiorowego, "Studia Iuridica Lublinensia" 12(2014), pgs. 43-54.

15. Mazurkiewicz G., Edukacja i przywództwo. Modele mentalne jako bariery rozwoju, Cracow 2012.

16. Mąkosa P., Największa jest mitość. Ewangelizacyjny katechizm młodych, Tarnow 2015.

17. Nalaskowski A., Szkoła jako dobro kultury wobec mechanizmów edukacji, "Paedagogia Christiana" 1(1997), pgs. 62-71.

18. Nowak M., Czy szkoła ma przekazywać wiedzę, czy té̇ wychowywać? "Paedagogia Christiana" 29(2012), no 1, Olczak A., Umowa społeczna z dzieckiem jako strategia pracy otwierajacej na społeczeństwo, http://www. ipp.uz.zgora.pl/ aolczak/teksty/21.pdf (Accessed: 01.22.2018).

19. Potocki A., Wychowanie religijne w polskich przemianach, Warsaw 2017.

20. Ratzinger J., God and the World. Trans. Henry Taylor, Ignatius Press, 2013.

21. Rutkowska E., Mediacje i inne sposoby rozwiazywania konfliktów w gimnazjum, Warsaw 2015.

22. Sobala-Zbroszczyk A., Szkoła jako środowisko wychowawcze, "Nowa szkoła" 5(1999), pgs. 5-12.

23. Struzik Z., Program wychowawczy oparty na wartościach, Warsaw 2007.

24. Szulakiewicz W., Świat idei edukacyjnych, Torun 2008.

25. Szymański M.S., O metodzie projektów, Warsaw 2000.

26. Śliwerski B., Program wychowawcy szkoty, Warsaw 2001.

27. Zając W., Idea Królestwa Bożego w nauczaniu katechetycznym. In Scripturae Lumen. Ewangelia o Królestwie, ed. A. Paciorek, Lublin 2009, pgs. 427-438.

28. Ziółkowski P., Samorząd uczniowski: idee, uwarunkowania i doświadczenia, Bydgoszcz 2014. 